\title{
Cultivating Alliances: The Local Organic Food Co-ops Network
}

\author{
Jennifer Sumner \\ University of Toronto \\ Cassie Wever \\ York University
}

\begin{abstract}
Although social movements can lose their way in neoliberal times, building alliances can help them to leverage their strengths and overcome their weaknesses, thus avoiding co-optation and "mission drift." One example of this strategy can be found within the co-operative movement: the Local Organic Food Co-ops Network in Ontario. A pilot study of six co-operatives in this organization reveals that they cultivate alliances in four ways: among member coops, through the creation of the network, with other types of organizations, and with other social movements. These alliances strengthen the co-operative movement, help to make the politics of alternative food systems work, influence the economy toward co-operation, and open up possibilities for establishing and maintaining a more sustainable food system.
\end{abstract}

\section{RÉSUMÉ}

Les mouvements sociaux, bien qu'ils puissent s'égarer à l'ère du néolibéralisme, peuvent établir des alliances afin de profiter de leurs atouts et surmonter leurs faiblesses, évitant ainsi la cooptation ou les déviations. On retrouve un exemple de cette stratégie d'alliance dans le cadre du mouvement coopératif en Ontario : The Local Organic Food Co-ops Network. Une étude pilote de six coopératives faisant partie de cette organisation révèle que celles-ci créent des alliances de quatre manières différentes : entre coopératives membres, grâce à la création du réseau même, avec d'autres types d'organisation et avec d'autres mouvements sociaux. Ces alliances renforcent le mouvement coopératif, aident à faire fonctionner les systèmes d'alimentation alternative, encouragent la collaboration économique et contribuent à établir et maintenir un système d'alimentation plus durable.

Keywords I Mots clés Alliance; Co-operative movement; Local Organic Food Co-ops Network; Social movement; Sustainable food system / Alliance; Mouvement coopératif; Local Organic Food Co-ops Network; Mouvement social; Système d'alimentation durable 


\section{Sumner \& Wever (2015)}

\section{CULTIVATING ALLIANCES: THE LOCAL ORGANIC FOOD CO-OPS NETWORK}

Many social movements have opposed the depredations of neoliberalism, but some of them could be considered ineffectual or even co-opted-caught in the narrowing of the "politics of the possible" (Guthman, 2008, p. 1180) that characterizes the neoliberal project. To overcome this problem, some movements have formed alliances in order to leverage their strengths while overcoming their weaknesses. Using a political economy framework, this article will present findings from a recent pilot study of the Local Organic Food Co-ops (LOFC) Network (2013) in Ontario, Canada. It will begin by looking at social movements, and then briefly discuss the co-operative movement, before describing the study and presenting the findings. Analysis of the data from the field research revealed that by cultivating alliances, the LOFC Network, although small in comparison to the overall food expenditures in the province, is creating a potent form of social, economic, and environmental sustainability that promotes participation, democracy, and sharing, supports a collaborative economy, and protects ecological integrity.

\section{SOCIAL MOVEMENTS}

A social movement can be understood as "a network of informal interactions between a plurality of individuals, groups and/or organizations, engaged in political or cultural conflict on the basis of a shared collective identity" (Diani, 1992, p. 13). Social movements are generally divided into two types: the so-called "old social movements," composed of organized labour, and the "new social movements," such as the environmental movement, the peace movement, and women's movements. While the old social movements are class based, practice recognized strategies, such as strikes and working to rule, and get involved in organized politics, the new social movements (NSMs) are more issue specific, cut across class lines, employ a wide variety of unconventional tactics, and operate more outside the realm of organized politics (McCarthy, 2000).

NSMs emerge from the near-dissolution of traditional politics. They contain the double prospect of autonomy and consolidation, but also the possibility of descent into sectarianism and political impotence. Should they take root locally and develop strong cords of political connectedness, they may turn out to be the one force capable of cracking the mould of corporate globalization (Ratner, 1997, pp. 275-276).

Corinne Gendron, Véronique Bisaillon, and Ana Isabel Otero Rance (2009) have refined the concept of NSMs by proposing new economic social movements-a new generation of social movements that focuses primarily on the economic sphere and influences the economy toward political or social ends. For example, some social movements engage in "buycotting" strategies, which are "based not only on the education and awareness of consumers but also on measures of traceability and labelling" (p. 72). By doing so, they argue, these movements pressure businesses on a sociopolitical level by using the economic status of the consumer or the investor, thus redefining, re-politicizing, and re-socializing economic transactions.

Social movements of every kind have a long history of resistance and change. From the labour movement through the movements associated with women, civil rights, the environment, and peace to the gay rights movement, antiglobalization movement, and new social economic movements, people have been acting collectively to challenge repressive laws and mores. While not all social movements are progressive (e.g., the white supremacist movement), the large majority ascribes to emancipatory values and seeks a more sustainable world.

The progressive orientation of social movements has been seriously challenged by the rise of neoliberalism, a theory of political-economic practices that proposes that human well-being can be best advanced by the 


\section{Sumner \& Wever (2015)}

maximization of entrepreneurial freedoms, supported by an institutional framework characterized by private property rights, individual liberty, free markets, and free trade (Harvey, 2006). By seeking to bring all human action into the domain of the market, neoliberalism promotes a disembedded market economy that has entailed a great deal of what Joseph Schumpeter (1994) referred to as "creative destruction"-the process of industrial mutation that constantly destroys and creates the economic structure. According to Harvey (2005), neoliberalism involves the creative destruction

not only of prior institutional frameworks and powers (even challenging traditional forms of state sovereignty) but also of divisions of labour, social relations, welfare provisions, technological mixes, ways of life and thought, reproductive activities, attachments to the land and habits of the heart. (p. 3)

Another example of this creative destruction is the co-optation of social movement visions of sustainability. In his study of the politics of co-optation, David Campbell (2001) sees co-optation as an ongoing process. He quotes Kenneth Dolbeare and Murray Edelman (1985), who provide a description of the policy dynamics that typically result when protest leaders challenge the status quo:

When the [co-optation] process has run its course, some new policies have been instituted, the basic complaints against the system have been reduced, the establishment has absorbed new members, and the system has acquired new defenders. The basic outlines of the system have again survived. (p. 508)

The co-optation of social movements can result in what McMurtry (2010) refers to as mission drift. For example, liberal feminism ignores the transformative change that drove the feminist movement by merely aiming to include women in the existing status quo. Demutualization strikes to the heart of the co-operative movement as some coops bend to the pressures of the neoliberal market and change into shareholder-based businesses. Fair Trade USA, for example, weakens the fair trade movement by breaking away from the global parent organization (Fairtrade International), setting up on its own, and certifying large-scale plantations. Organic twinkies negate the ethic of the organic pioneers who believed in healthy soils, plants, animals, people, and communities, not an organic version of an infamous junk food. These are all examples of the co-optation of social movements under the relentless onslaught of neoliberalism. Given the potential for co-optation, what options do social movements have?

To begin with, it is important to recognize that all social movements have both strengths and weaknesses. For example, women's movements have done much to improve the status of women around the world, but have been dominated by white, middle-class activists who have been accused of neocolonialism by women in developing countries (see, for example, Day, 2008). The labour movement has brought enormous benefit to the lives of working people, but has often ignored the environment, associating environmental protection with the loss of jobs (see, for example, Sawchuk, 2009). In an era of unrelenting neoliberalism, social movements must learn to leverage their strengths in new ways and overcome their weaknesses by forming alliances (Sumner, McMurtry, \& Renglich, 2014). We can find an inspiring example within the co-operative movement.

\section{THE CO-OPERATIVE MOVEMENT AND THE LOCAL ORGANIC FOOD CO-OPS NETWORK}

A co-operative is an autonomous association of persons united voluntarily to meet their common economic, social, and cultural needs and aspirations through a jointly owned and democratically controlled enterprise (ICA, 2015). As 


\section{Sumner \& Wever (2015)}

democratic, member-owned, and member-operated organizations whose defining feature is membership control, co-operatives aim to meet the membership's economic and social needs (McMurtry, 2010).

Over time, individual co-operatives have coalesced into a social movement with global reach, spurred by the principle of cooperation among co-operatives, formalized in 1966, but dating back to the Rochdale Pioneers' grand vision of a co-operative commonwealth (Quarter, 1992). The co-operative movement, like other social movements, has long been involved in resistance and change. Born out of unfair treatment of consumers in Rochdale, England, more than 150 years ago, it spread around the world, with the movement now found in over 65 countries and made up of co-ops that serve the needs of consumers, producers, and workers (ICA, 2015).

While the co-operative movement can be found in most areas of human endeavour, it is particularly prevalent within the realm of food. Indeed, alternative food systems feature co-operatives at almost every level of development, and in fact they are often initiated by co-ops. Further, co-operatives themselves emerge as a distinct form of business with the first formal co-operative in Rochdale having as its motivation quality food-namely unadulterated grain-for its members, which the emerging industrial and capitalist food system in England was loath to ensure. From these humble beginnings, the co-operative movement has been, and continues to be, uniquely placed to feature centrally in any alternative food system focused on a sustainable future.

For this reason, the co-operative movement can be understood in terms of Gendron et al.'s (2009) new social economic movements. While it may not be new, the co-operative movement uses economic forms of social pressure. For example, cooperation among co-operatives (the sixth co-operative principle) can be understood as a form of buycott-deliberately choosing to buy from other co-ops instead of non-co-ops. By operating in the economic sphere, the co-operative movement contributes to a redefinition, re-politicization, and re-socialization of economic transactions.

In common with all social movements, the co-operative movement exhibits both strengths and weaknesses. As a social economic movement, its strengths include a united voice in the market, a democratic platform for decisionmaking, and a collective approach to problem solving. One of its weaknesses is its lack of formal commitment to the environment: none of the seven co-operative principles address this vital aspect of human life. In an age characterized by climate destabilization, soil degradation, and water scarcity-much of it the result of neoliberal policies-the co-operative movement's insufficient engagement with the environment needs to be directly addressed.

One group of co-operatives, however, has been leveraging its strengths while overcoming its weaknesses by forging a novel suite of alliances. The Local Organic Food Co-ops (LOFC) Network (2013) is a coalition of cooperatives that specialize in locally and sustainably produced food in the province of Ontario. From an initial group of 18 co-ops in 2010, the LOFC Network now includes over 75 active co-ops and is still growing. It is housed and supported by the Ontario Natural Food Co-op, an organization that brings to market natural, organic, and local foods and products-all within a co-operative framework (ONFC, 2015). The purpose of the LOFC Network reflects its status as part of a social economic movement: to educate about and advocate for local and organic agriculture and food co-ops; to facilitate and support the growth of existing co-ops; and to connect and scale toward regional food processing and distribution hubs (LOFC Network, 2013). In spite of the variety of organizational models within the network-farmer-owned, eater-owned, worker-owned, and multistakeholder-all the co-ops within the network have six common characteristics: 


\section{Sumner \& Wever (2015)}

1. Bringing local farmers and eaters closer together;

2. Growing and supplying fresh, healthy food locally;

3. Keeping money in the community;

4. Trading fairly, whether domestically or internationally;

5. Saving energy, building the soil, and protecting water; and

6. Celebrating good food, culture, and community (LOFC Network, 2013).

Unlike the ruthlessly competitive neoliberal market, the LOFC Network shares information and creates a platform for collaboration and cooperation in the realm of food-all with the aim of establishing a sustainable food system.

\section{THE STUDY}

This article is based on a pilot study of the LOFC Network that was funded by a Social Sciences and Humanities Research Council (SSHRC) Institutional Grant administered through the Ontario Institute for Studies in Education (OISE) of the University of Toronto (UT). It involved semi-structured interviews of seven people involved in six coops (Garden City Food Co-operative, Eat Local Sudbury, On the Move Organics, the Mustard Seed Co-op, the Karma Project, and Karma Co-op), plus the animator of the LOFC Network, Hannah Renglich. Five interviews were conducted face-to-face and three by telephone, using a set of open-ended questions, with each interview lasting approximately one hour. Participants were suggested by the animator and represent a mix of old and new member co-ops from around the province. While this sampling strategy is not necessarily representative of all the co-ops in the LOFC Network, it provides a rich picture of the possibilities inherent in the network, while laying the groundwork for a larger study.

\section{FINDINGS AND DISCUSSION}

The co-operatives in the LOFC Network cultivate alliances in four main ways: among member co-ops, through the creation of the network, with other types of organizations, and with other social movements.

\section{Cultivating alliances among co-ops}

For over a century, co-operatives have been encouraged to follow the sixth principle of co-operation, "cooperation among co-operatives." Within the LOFC, this cooperation takes many forms, including sharing resources, initiating relationships, mentoring, actively supporting one another, and participating in the evolution of the network and systems-level network projects.

One of the most common ways in which participating co-operatives are collaborating is by sharing resources and initiating relationships. This has been particularly important for newer co-ops as they begin their journey, because it allows them to avoid common pitfalls and find inspiration from the work of others. For example, two people involved in the creation of one of the co-ops visited over 35 other co-ops, within and beyond the network, and read every piece of information circulated by other member co-ops and the network's animator before opening a storefront.

Another form of co-operation among co-operatives is mentoring. While it might be assumed that older co-ops would mentor newer co-ops through their initial phases, in reality many of the relationships between co-ops in the LOFC Network are actually predicated upon a form of "mutual mentorship." As co-ops grow and develop they are experiencing and overcoming challenges, such as expansion, member engagement, business planning and strategic development, and sourcing from the local supply chain. Co-ops at all levels of development are offering one another insights into these and other areas through peer-to-peer workshops, skill and information sharing, and 


\section{Sumner \& Wever (2015)}

open lines of communication. At an annual assembly, co-ops host and attend sessions on sourcing, governance, environmental sustainability, and member engagement, among a plethora of other topics. This collaborative sharing, in which no particular co-op has all of the solutions and the learning is co-created, is inherently democratic and an integral part of being a co-op.

This resource sharing and mentorship often goes beyond passive communication and involves active participation and engagement. In a very salient example, an established member co-op was nearly at the point of closing its doors when it reached out to the other members of the network for assistance. Co-ops at all stages of development-some were not even officially opened at the time-came together and offered support and resources that were instrumental in keeping this co-op in business. Nearly every interviewee discussed it as a primary example of how co-ops in this movement are working to support one another. Other co-ops have helped one another to develop promotional videos in order to receive funding, and actively share supplier lists and business information. These relationships highlight some of the strengths of the co-operative model, where co-ops not only support one another but actively work together.

The most overarching way in which co-ops work together in this alliance has been the creation of the network itself, which was formed as a response to a request to build a support system for cooperatives. Today, the collaborative relationships between co-ops inform the ongoing creation and evolution of the Network's role and identity. For example, regional relationships between co-operatives have made it clear there is a need and desire for regional distribution networks that would allow smaller co-ops to combine their purchasing and transportation power to support local growers. These networks would also make inter-regional trade of products possible, such as accessing beef from northern Ontario and produce from southwestern Ontario. With this in mind, the LOFC Network, through the Ontario Natural Food Co-op (ONFC), applied for and received a grant for 2014/2015 from the Local Food Fund to determine the viability of regional food hubs in the four areas represented by the True North Community Co-op (far north), Eat Local Sudbury (northern Ontario), On the Move Organics (southwestern Ontario), and the Ottawa Valley Food Co-op (eastern Ontario). This new approach to eating locally adds the dimensions of eating well and justly, closer to home, which will be discussed more in-depth later in the article.

As the number of co-ops continues to increase, they are facing challenges, such as runaway growth, disputes over the source of organic products, tensions between building the business and paying employees fairly, and inadequate locations. The network was developed to help them address such problems.

\section{Cultivating alliances through creating a network}

Following the sixth principle, co-ops can band together in what Lynn M. Harter (2004) refers to as "nets of collective action" (p. 96). These co-operative support organizations help their "constituent cooperatives survive by effectively consolidating resources in order to better intersect with organizations in a larger bureaucratic system" (Harter \& Krone, 2001, p. 249). Alliances take on different forms, such as federations, value chains, and-the focus of this article-networks.

In general, networks can be understood as a collection of relationships that connect groups and can both impose restraints that limit options and provide resources (Johnson, 2000). Charles Levkoe (in press) contends that networks can increase the success of social movements through not only alliance building, but also the diffusion of ideas and practices, more sustained levels of activity, and more desirable, legitimate, and democratic forms of political organization. In addition, he sees networks as sites for sharing and exchanging ideas, identities, and frames, thus contributing to a more generalized discourse and practice. In sum, he maintains, networks are central 


\section{Sumner \& Wever (2015)}

to developing solidarity across sectors, scales, and places and for engaging in social and/or political action-all factors that make social movements successful.

Within the co-operative movement, a network manifests as a group of co-operatives that work together without establishing a lead co-op (unlike a federation, which involves a lead co-operative owned by a group of cooperatives, such as Federated Co-operatives Limited and La Coop fédérée, or the umbrella organizations, known as apex organizations, such as the Ontario Co-operative Association and Co-operatives and Mutuals Canada). The LOFC Network was created so that both established and new co-operatives could work together to address their needs. In 2009, the Ontario Co-operative Association hosted a meeting in Toronto to bring together a number of new co-operatives with three established co-operatives to encourage information sharing and potential collaboration. The meeting had four objectives (Christianson, 2009). First, it aimed to help foster and maintain connections between co-operatives working in the areas of local and organic food and to provide sources of support for their work. Second, it planned to develop a strategy that would help co-ops grow by allowing them to share experiences and knowledge with each other. Third, it wanted to learn how the co-op model was working in various communities, and how it could share those experiences with other communities across Ontario that are also interested in developing local organic food co-operatives. Fourth, it wished to provide board governance training and technical assistance. As a result of a follow-up meeting in 2010, the Local Organic Food Co-ops initiative was born, and was to be housed and supported by the Ontario Natural Food Co-op (ONFC); the term "network" was added at a third assembly of the involved co-ops in 2011. The ONFC then hired Hannah Renglich, who has an MA in Natural Resources and Peace and a background in food security organizations, as the first network animator. Her job was to coordinate and develop all areas related to the network, as well as its relationship to the ONFC. Under her guidance, the network came to recognize the importance of alliances for survival in a competitive market:

Through the sharing of information and exploration of innovations in food-based social enterprise, the co-ops are co-creating the network as a platform for internal strengthening and province-wide collaboration. (LOFC Network, 2013)

The network is made up of over 75 co-operatives of all types: producer, consumer, worker, and multistakeholder. Although several are located in the northern part of the province, most can be found across southern Ontario, from Windsor to Ottawa. Some, such as Karma Co-op and the Big Carrot, have been active for decades, while others, such as the Garden City Food Co-operative and the Mustard Seed Co-op, are just beginning. Overall, this network of food and farming co-ops works toward "a co-operative and sustainable food system by strengthening the food coop movement in Ontario" (LOFC Network, 2013). Analysis of the interview data shows how the network contributes to economic, social, and environmental sustainability, and to an alternative food system that is more sustainable than the current industrial food system.

In terms of economic sustainability, the network helps new co-ops get started and established co-ops survive. In both cases, the sharing of knowledge and information allows co-ops to receive constructive feedback and advice, make better choices, learn from others, and avoid reinventing the wheel when it came to running a business. One participant emphasized the importance of having successful co-operative food-related businesses spread across the province that all share similar ethical principles and act as nodal points for the distribution and redistribution of local organic food. Another participant stated, "I don't know if we'd be here if it wasn't for the Network. ... I've learned lots about what it means to be [a] co-op from the Network. How to run meetings, ideas for AGMs ... I just feel like we've learned everything about being a food co-op from the Network, and from other co-ops, and you know, [starting a co-op] is something that would be impossible to do without any support from outside." 


\section{Sumner \& Wever (2015)}

In terms of social sustainability, the network gives individual co-ops credibility in the eyes of the public. It also helps those co-ops broadcast their mission and let people know what they are doing, especially when the network animator participates in community meetings and helps to connect the community to the co-ops. The existence of the network, both symbolically and as a group of people who share similar values, contributes greatly to the sense that there is a "community of food practice" (Friedmann, 2012, p. 27) in local organic food co-ops. Several co-ops stated that the network provides both moral and practical support, a sense of "being a part of something larger," and a feeling of solidarity. These social aspects of the network are often the impetus to continue working through challenges. In addition, the culture of sharing that infuses the network allows member co-ops to share very practical tools, such as business plans, human resources (HR) lists, contracts, supplier lists, and information about equipment costs. As one participant stated, "[B]ecause it's a co-op network, it's amazing how much people share information differently than through a normal business network. There's just not nearly "... the [same] competition or protecting of your intellectual property."

The co-ops also include aspects of social sustainability in their day-to-day operations, such as providing living wages for employees, supporting local producers, engaging volunteers, providing education through workshops, classes, advertising, and events, and offering community spaces such as kitchens. Several interviewees discussed how their co-op had become a place for people to meet each other and build community. Thanks in part to the network, the co-op model is also being used to transition some food businesses into community-owned endeavours; as the animator shared, "It's an interesting process for a community to suddenly have a business open all of its books to them, and welcome them in as decision makers and investors and participants." While it is not unique to only food co-ops, transitioning to a co-op will allow these businesses to continue to play important roles in their communities, without relying on a single proprietor to carry the workload.

In terms of environmental sustainability, the culture of sharing spreads to environmentally friendly initiatives, such as buying from and with other local co-ops and strengthening the local economy and local farmers. The network also creates a space to share concerns about the environment and climate change, with a section on the website dedicated to environmental sustainability. In addition, it helps forefront environmental issues by circulating articles on such topics as conservation, environmental stewardship, neonicotinoids, and the impact of chemicals on the environment. Co-ops share information on how to become a zero-waste store, and how to establish an "environmental scorecard" to communicate to members and customers their goals and progress in achieving environmental sustainability goals. By joining up like-minded activists in the ecological arena, the network also gives members the support and strength to move forward and fulfill their mission, especially in the area of more local food procurement. In this regard, every co-op in the network sets purchasing priorities and defines and prioritizes local food depending on its particular context and mission. However, all the co-ops interviewed discussed the importance of "local," meaning they had a direct relationship with their producers and suppliers built on trust and similar ethical principles. While not every member co-op stocks strictly certified organic produce, they all aspire toward organic principles through ensuring that producers and suppliers have an "ecological ethic of care" in their work. Notwithstanding the tensions around the conventionalization of organic agriculture and organic certification issues (see Sumner, 2015; Sumner \& Llewelyn, 2011), being part of a network reinforces the good intentions associated with this ethic of care because the members share knowledge, provide support, and make it economically feasible to act ethically.

The LOFC Network also contributes to building and maintaining an alternative to the global corporate food system. To begin with, the network offers a fundamentally different way of looking at food and then weaves the co- 


\section{Sumner \& Wever (2015)}

operatives together "so that the province is a quilt of amazing food system work and partnership." This is reinforced by building shared knowledge and skills for a sustainable food system, hosting conferences and workshops to bring together ideas about sustainable food systems, and making people aware of what is happening elsewhere in terms of smaller scale, alternative, or non-industrial, non-centrally controlled food enterprises.

The network also helps co-ops learn the practicalities of feeding a population sustainably. It is in a unique position to develop a co-operative distribution system that trades provincially, nationally, and internationally while still adhering to co-operative values. It can link member co-ops to markets that value what they are producing and grow more opportunities by connecting different markets and people. In addition, through communication, resource sharing, and trade opportunities, the network enables small-scale, sustainable, local, organic food co-ops to compete in a system that is structured to favour huge multinationals, and to avoid ending up as "siloed operators fighting on multiple fronts."

And finally, the network represents a manifestation of food sovereignty, which focuses on the right of peoples and governments to determine their own agriculture systems, food markets, environments, and modes of production (Koç, Sumner, \& Winson, 2012). In effect, the network provides space for people to overcome the alienation from food that is reinforced by the global corporate food system and to learn to (re-)engage with food in meaningful ways while creating a sense of community among members and the public. One interviewee described what she was gaining through the network and through being involved in a co-op as learning and practicing the skills required to create a better world-skills such as democratic practices, consensus building, the logistics of sourcing locally, and community engagement. While she expressed feeling challenged at times by trying to run a business within the constraints of a capitalist economic system, she felt that the co-op model and the support provided through the network allowed her to participate in a business that is more aligned with her values, and through which community could be created and supported.

\section{Cultivating alliances with other organizations}

The co-operatives that make up the LOFC Network have also forged alliances with other organizations. For example, the network has built an alliance with Sustain Ontario, an umbrella organization that focuses on a food system that is healthy, ecological, equitable, and financially viable-all aspects of sustainability. Membership is open to a range of groups, food enterprises (businesses and farms), and the public sector, and encompasses such diverse organizations as Afri-Can FoodBasket, the Canadian Environmental Law Association, the Chathum-Kent Public Health Unit, the Ecological Farmers of Ontario, and the Greater Sudbury Food Policy Council. This alliance has helped the LOFC Network leverage its position as a newcomer in the realm of local food, allowing it to achieve greater visibility and support transformative change in the food system. The LOFC Network has also received moral and in-kind support from the Ontario Cooperative Association, Food Secure Canada, Co-ops and Mutuals Canada, and the Organic Council of Ontario, among others. Attendees at the 2015 annual assembly included supporters from FarmStart and the National Farmers Union. Additionally, the network recently teamed up with the Ecological Farmers Association of Ontario (EFAO) and the Greenbelt Farmers Market Network to offer a workshop in "High Bionutrient Crop Production," which provided valuable learning for farmer members and those interested in learning about ecological agriculture. Finally, the network is connected to academic groups, such as the Canadian Association for Studies in Cooperation, the Canadian Association for Food Studies, and the Nourishing Communities Research Group. These alliances connect the network to broader food-systems-level work and create opportunities for the network's role to be documented and shared with others. 


\section{Sumner \& Wever (2015)}

\section{Cultivating alliances with other social movements}

The co-operatives in the LOFC Network cultivate deep alliances with two other social movements, both of which work toward various forms of sustainability: the organic movement and the local food movement.

In his authoritative text, Philip Conford (2001) dated the start of the organic movement from 1926, based on a confluence of events and initiatives occurring in inter-war Britain and continental Europe. Then, as now, the organic movement arose in reaction to the industrialization, marginalization, and destruction of rural as well as urban landscapes (Fromartz, 2006). The impetus for what coalesced into the organic movement came not simply from farmers but also from those working with the downstream impacts of the industrialization of agriculture, whether in deteriorating public health, soil infertility and pest outbreaks, livestock disease epidemics, rural community disintegration, or environmental degradation. In spite of the dubious politics associated with some members (see Reed, 2001), what unified these organic pioneers was the shared perception that soil, crop, livestock, and human health, as well as family and community health, were integrally and functionally related.

The organic movement spread in earnest after World War II. Bolstered by the back-to-the-land movement in the 1960s, it grew in strength and numbers to include a wider range of movement players: chefs, restaurateurs, nutritionists, green entrepreneurs, farming associations, back-to-the-landers, disaffected conventional farmers, conservationists, environmentalists, academics, and co-operatives-all focused on organic food. Today, it has become an international movement dedicated not only to resisting the industrialization of food and agriculture but also to providing a model of alternative ways of eating and living, and to highlighting the social, ecological, and economic goods and services organic agriculture provides (Lynch, Sumner, \& Martin, 2014). Today's organic movement has been critiqued on a range of issues, including gender bias (Sumner \& Llewelyn, 2011), lack of commitment to social sustainability (Shreck, Getz, \& Feenstra, 2006) and co-optation (Jaffee \& Howard, 2009), but it continues to evolve and mature. This maturation is reflected in the many strands within the movement, such as those who follow agro-ecological approaches, non-organic but environmentally concerned farmers (e.g., Practical Farmers of lowa), and followers of holistic resource management. The success of the movement is illustrated by the rise of "greenwashing" and questionable forms of "sustainable agriculture" that try to capitalize on the growing market in organics.

One strength of the organic movement is its attention to environmental sustainability. Its weakness lies in its lack of social parameters, in spite of the efforts by the International Federation of Organic Agriculture Movements (IFOAM) to encourage them. For example, Patricia Allen and Carolyn Sachs (1993) have argued for forms of organic certification that take into account the social conditions of farm workers. This highlights, among other things, that food could be grown that was strictly organic, but produced using slave labour. An alliance with the co-operative movement bolsters the environmental credentials of co-ops, while providing the missing social sustainability to the organic movement. For example, analysis of the data from the study reveals concern for fair wages and safe working conditions, as well as adherence to the co-operative principles of democratic decision-making and an ethic of co-operation, not exploitation. Another criticism of organic agriculture is that the organic standards can be technically applied without an accompanying paradigm shift to farming as an ecological practice. When this happens, organic products and practices can merely be substituted for conventional synthetic chemicals and practices, resulting in, for example, giant monocrops of organic lettuce requiring massive inputs from offsite sources. The interviews revealed that co-ops in the LOFC Network approach this issue by establishing direct, trusting relationships with producers, with the understanding that an "ecological ethic of care" will be applied throughout their farming practices. 


\section{Sumner \& Wever (2015)}

The second alliance the co-operatives in the LOFC Network have forged with other social movements involves the local food movement. This relatively new movement has been defined as "a collaborative effort to build more locally based, self-reliant food economies-one[s] in which sustainable food production, processing, distribution, and consumption [are] integrated to enhance the economic, environmental, and local health of a particular place" (Feenstra, 2002, p. 100). Made up of a loose coalition of individuals, groups, and organizations that promote local food production and self-sufficiency, the local food movement is expressed in ongoing projects, such as farmers' markets, community-supported agriculture (CSA) programs, urban agriculture, farm-to-school meals, and local food festivals.

The local food movement emerged as a form of resistance to the entrenchment of the global corporate food system and its "faceless, placeless food that is shrink-wrapped in the sterile confines of the supermarket aisle" (Sumner \& Wever, in press). A study by the Canadian Co-operative Association found that there were approximately 2,300 local food initiatives in Canada, with 24 umbrella organizations supporting and promoting these initiatives and over 200 co-operatives involved with local food (CCA, 2009). As the movement expands, the pressures to scale-up increase - with all the possibilities and problems such a move would entail (see Mount, 2012).

To complicate matters, the word "local" is highly contested, meaning anything from the surrounding community (Selfa \& Qazi, 2005), to one hundred miles (Smith \& McKinnon, 2007), a three-hour drive (Pollan, 2006), a foodshed (Kloppenburg, Hendrickson, \& Stevenson, 1996), or a province (CELA, 2013). As Laura DeLind (2010) notes, the very amorphousness of the term has attracted an odd assortment of adherents to the local food movement: survivalists, environmentalists, artisans, union labour, and both the healthy and the unhealthy. The result is a term that has become easy to swallow and serves the status quo, thus "losing track of its own selfreflexive, and often contradictory and embodied nature ... [and] much of its potential for system resilience" (p. 275). Not surprisingly, this contested term is both a strength and a weakness of the movement.

The strength of the local food movement is its dedication to raising awareness about local food, local farmers, and the local economy, all of which have been bypassed by the global corporate food system. Its weakness has been summed up in a seminal concept developed by Branden Born and Mark Purcell (2006) called the local trap. In essence, they argue that scale is a social construct, so there is nothing inherent about any scale; that is, local is not automatically more sustainable or more just than any other scale. As a result, scale is not an end in itself, but a strategy based on the agenda of those who are empowered by the scale.

Many champions of local food have touted its presumed merits, from increased sustainability to greater social justice. These empty claims can only be substantiated when local food is backed by an agenda based on a set of values that promote sustainability or social justice. That agenda can come from the co-operative movement, with its prescribed values and seven co-operative principles. Analysis of the data from the study reveals that members operated from an agenda that included democratic decision-making, education and outreach, an ethic of cooperation, and a deep concern for community-a prime example of how alliances can help to overcome social movement weaknesses. The local food movement, in turn, can bolster the co-operative movement's weakness in the area of the environment by reducing the distance food travels from field to fork (called "food miles") and reinforcing its economic and social commitments to community.

\section{CONCLUSION}

The Local Organic Food Co-ops Network exemplifies some of the synergies that a social economic movement such as the co-operative movement can achieve by cultivating alliances-among co-ops, through creating a network, 


\section{Sumner \& Wever (2015)}

with other types of organizations, and by way of other social movements-all for the purpose of increasing sustainability in a world that is becoming increasingly unsustainable. These four main ways of cultivating alliances help the co-operatives in the LOFC Network to leverage their strengths while addressing their weaknesses. David Goodman, Melanie Dupuis, and Michael Goodman (2014) maintain that such alliances-between groups with different interests but some overlapping agendas-make the politics of alternative food systems work. If these politics are focused on increasing sustainability, then the possibilities for establishing and maintaining a more sustainable food system open up. Although this pilot study only dealt with a small number of the co-ops in the LOFC Network, the rich picture of alliance building they provided clearly indicates a viable strategy for social economic movements to pursue in search of social change, particularly in the economic sphere.

Are there any key features inherent in co-operatives that allow them to create successful alliances and that other social movements could learn from? In his study of co-operative movements in developing countries, Patrick Develtere (1993) posited a social movement triad-three components of all social movements that help them realize their objectives. The first component of the triad is the movement's ideology or vision, which outlines a desirable society based on a set of particular values and how to achieve it. The second component is the movement's praxis or action, which "embodies the spontaneity of all social movements and is responsible for the mobilization and participation of the membership base" (p. 182). The third component involves the development of an organizational structure, however minimal. According to Develtere (1993), each component interacts dialectically with the others to create, in the best scenario, a balanced and simultaneous involvement of the three forcesotherwise the movement loses strength, cohesion, and legitimacy.

Develtere's (1993) social movement triad can be fruitfully applied to a social economic movement such as the cooperative movement, including the LOFC Network. First, in terms of ideology or vision, the co-operative values and the seven principles provide a moral touchstone for building alliances. Second, in terms of praxis or action, the amount of inter-cooperation among co-operatives is a working model that is based in alliances. Third, in terms of organization, the forms of incorporation and the organizational structures of co-operatives are collective and democratic by nature and encourage alliance making. These three components of co-operatives have allowed them to create successful alliances for many years and thus support a social economic movement such as the cooperative movement. For the LOFC Network, cultivating alliances reinforces its strengths while addressing some of its weaknesses, resulting in a more powerful potential to broaden the politics of the possible, influence the economy toward co-operation, and normalize a sustainable food system.

\section{WEBSITES}

Afri-Can FoodBasket, http://blog.africanfoodbasket.com/

Big Carrot, http://thebigcarrot.ca/home/

Canadian Association for Food Studies, http://cafs.landfood.ubc.ca/en/

Canadian Association for Studies in Cooperation, http://www.coopresearch.coop/

Chathum-Kent Public Health Unit, http://ckphu.com/

Co-operatives and Mutuals Canada, http://www.canada.coop/

Eat Local Sudbury, http://www.eatlocalsudbury.com/

Ecological Farmers of Ontario, https://efao.cal

Fair Trade USA, http://fairtradeusa.org/

Federated Co-operatives Limited, https://www.coopconnection.ca/wps/portal/fclretail/FCLInternet/AboutUs/FCL/

Garden City Food Co-operative, http://www.gardencityfoodcoop.cal

Greater Sudbury Food Policy Council, http://sudburyfoodpolicy.com/ 


\section{Sumner \& Wever (2015)}

International Federation of Organic Agriculture Movements, http://www.ifoam.bio/

Karma Co-op, http://www.karmacoop.org/

Karma Project, http://www.thekarmaprojectinc.com/

La Coop fédérée, http://web.lacoop.coop/en/

Mustard Seed Co-op, http://mustardseed.coop/

Nourishing Communities Research Group, http://nourishingontario.ca/research/

On the Move Organics, https://www.onthemoveorganics.cal

Ontario Co-operative Association, http://www.ontario.coop/

Ontario Natural Food Co-op, http://www.onfc.cal

Ottawa Valley Food Co-op, http://www.ottawavalleyfood.org/

Sustain Ontario, sustainontario.com

The True North Community Co-op, http://truenorthcoop.ca/

\section{REFERENCES}

Allen, P., \& Sachs, C. (1993). Sustainable agriculture in the United States: Engagements, silences and possibilities for transformation. In P. Allen (Ed.), Food for the future: Conditions and contradictions of sustainability (139-167). New York, NY: Wiley.

Born, B., \& Purcell, M. (2006). Avoiding the local trap: Scale and food systems in planning research. Journal of Planning Education and Research, 26(2), 195-207.

Campbell, D. (2001). Conviction seeking efficacy: Sustainable agriculture and the politics of co-optation. Agriculture and Human Values, 18, 353-363.

CCA. (2009). Working together for local food: Co-operative profiles and resource guide. Ottawa, ON: Canadian Cooperative Association. URL: http://www.coopscanada.coop/assets/firefly/files/files/Local_Food_Full.pdf [July 27, 2015].

CELA. (2013). Ontario Local Food Act, 2013: A model bill. Toronto, ON: Canadian Environmental Law Association. URL: http://s.cela.ca/files/891ModelLocalFoodBill_0.pdf [September 18, 2015].

Christianson, R. (2009). Creating a sustainable food system for Ontario: Supporting the development of local organic food co-operatives. [Discussion Paper]. Guelph, ON: Ontario Co-operative Association.

Conford, P. (2001). The origins of the organic movement. Edinburgh: Floris Books.

Day, L.R. (2008). "Bottom power": Theorizing feminism and the women's movement in Sierra Leone (1981-2007). African and Asian Studies, 7(4), 491-513.

DeLind, L.B. (2011). Are local food and the local food movement taking us where we want to go? Or are we hitching our wagons to the wrong stars? Agriculture and Human Values, 28, 273-283.

Develtere, P. (1993). Cooperative movements in the developing countries: Old and new orientations. Annals of Public and Cooperative Economics, 64(2), 179-208.

Dolbeare, K.M., \& M.J. Edelman (1985). American Politics: Policies, Power, and Change. Lexington, Massachusetts: D.C. Heath and Company.

Diani, M. (1992). The concept of social movement. The Sociological Review, 40(1), 1-25.

Feenstra, G. (2002). Creating space for sustainable food systems: Lessons from the field. Agriculture and Human Values, 19(2), 99-106.

Friedmann, H. (2012). Changing food systems from top to bottom: Political economy and social movements perspectives. In M. Koç, J. Sumner, \& A. Winson (Eds.), Critical perspectives in food studies (pp. 16-32). Toronto, ON: Oxford University Press.

Fromartz, S. (2006). Organic, INC. Natural foods and how they grew. Orlando, FL: Harcourt, Inc.

Gendron, C., Bisaillon, V. \& Otero Rance, A.I. (2009). The institutionalization of fair trade: More than just a 


\section{Sumner \& Wever (2015)}

degraded form of social action. Journal of Business Ethics, 86, 63-79.

Goodman, D., Dupuis, E.M., \& Goodman, M.K. (2014). Alternative food networks: Knowledge, practice and politics. New York, NY: Routledge.

Guthman, J. (2008). Neoliberalism and the making of food politics in California. Geoforum, 39, 1171-1183.

Harter, L.M. (2004). Masculinity(s), the agrarian frontier myth, and cooperative ways of organizing: Contradictions and tensions in the experience and enactment of democracy. Journal of Applied Communication Research, 32(2), 89-118.

Harter, L.M., \& Krone, K.J. (2001). The boundary-spanning role of a cooperative support organization: Managing the paradox of stability and change in non-traditional organizations. Journal of Applied Communication Research, 29(3), 248-277.

Harvey, D. (2005). A brief history of neoliberalism. Oxford, UK: Oxford University Press.

Harvey, D. (2006). Neo-liberalism as creative destruction. Geografiska Annaler, 88B(2), 145-158.

ICA. (2015). International Co-operative Association. URL: http://ica.coop [October 5, 2015].

Jaffee, D. \& Howard, P. (2009). Corporate co-optation of organic and fair trade standards. Agriculture and Human Values, 27, 387-399.

Johnson, A.G. (2000). The Blackwell dictionary of sociology. Malden, MA: Blackwell Publishers.

Kloppenburg, J. Jr., Hendrickson, J., \& Stevenson, G.W. (1996). Coming in to the foodshed. Agriculture and Human Values, 13(3), 33-42.

Koç, M., Sumner, J., \& Winson, A. (Eds.). (2012). Critical perspectives in food studies. Toronto, ON: Oxford University Press.

Levkoe, C.Z. (In press). Alternative food initiatives, food movements and collaborative networks: A pan-Canadian perspective. In M. Koç, J. Sumner, \& A. Winson (Eds.). Critical perspectives in food studies, second edition. Toronto, ON: Oxford University Press.

LOFC Network. (2013). Welcome. Local Organic Food Co-ops Network. URL: http://cultivatingfoodcoops.net/uncategorized/welcome-bienvenue-2/ [October 5, 2015].

Lynch, D., Sumner, J., \& Martin, R. (2014). Framing the social, ecological and economic goods and services derived from organic agriculture in the Canadian context. In S. Bellon, S. Penvern, \& I. Savini (Eds.), Organic farming, prototype for sustainable agricultures (pp. 347-365). Paris, FR: National Institute for Agricultural Research (INRA).

McCarthy, J. (2000). Social movement. In R.J. Johnston, D. Gregory, G. Pratt, \& M. Watts (Eds.), The dictionary of human geography (pp. 758-759), Fourth Edition. Malden, Mass: Blackwell Publishers Ltd.

McMurtry, J.J. (2010). Living economics: Canadian perspectives on the social economy, co-operatives and community economic development. Toronto, ON: Emond Montgomery Publications.

Mount, P. (2012). Growing local food: Scale and local food systems governance. Agriculture and Human Values, $29,107-121$.

ONFC. (2015). Ontario Natural Food Co-op. URL: http://www.onfc.ca/mission-vision-values [July 27, 2015].

Pollan, M. (2006). No bar code: The next revolution in food is just around the corner. Mother Jones, May/June, 36-45.

Quarter, J. (1992). Canada's social economy: Co-operatives, non-profits and other community enterprises. Toronto, ON: James Lorimer and Company.

Ratner, R.S. (1997). Many Davids, one Goliath. In W.K. Carroll (Ed.), Organizing dissent: Contemporary social movements in theory and practice (pp. 271-286). Toronto, ON: Garamond.

Reed, M. (2001). Fight the future! How the contemporary campaigns of the UK organic movement have arisen from their composting of the past. Sociologia Ruralis, 41(1), 131-145.

Sawchuk, P. (2009). Learning, labour and environmentalism: Canadian and international prospects. Canadian Journal for the Study of Adult Education, 21(2), 37-52. 


\section{Sumner \& Wever (2015)}

Schumpeter, J.A. (1994). Capitalism, socialism and democracy. London, UK: Routledge. (Originally published in 1942)

Selfa, T., \& Qazi, J. (2005). Place, taste, face-to-face? Understanding producer-consumer networks in "local" food systems in Washington State. Agriculture and Human Values, 22, 451-464.

Shreck, A., Getz, C., \& Feenstra, G. (2006). Social sustainability, farm labor, and organic agriculture: Findings from an exploratory analysis. Agriculture and Human Values, 23, 439-449.

Smith, A., \& MacKinnon, J.B. (2007). The 100-mile diet: A year of local eating. Toronto, ON: Random House.

Sumner, J. (2015). Standards as a commons: Private agri-food standards as governance for the 99 percent. Canadian Food Studies, 2(1), 113-132.

Sumner, J., \& Llewelyn, S. (2011). Organic solutions? Gender and organic farming in the age of industrial agriculture. Capitalism, Nature, Socialism, 22(1), 100-118.

Sumner, J., McMurtry, J.J., \& Renglich, H. (2014). Leveraging the local: Co-operative food systems and the Local Organic Foods Co-op Network in Ontario, Canada. Journal of Agriculture, Food Systems and Community Development, 4(3), 47-60.

Sumner, J., \& Wever, C. (In press). Pedagogical encounters: Critical food pedagogy and transformative learning in the school and community. In C. Anderson, J. Brady, \& C. Levkoe (Eds.), Conversations in food studies: Transgressing boundaries through critical inquiry. Winnipeg, MB: University of Manitoba Press.

\section{ABOUT THE AUTHORS / LES AUTEURS}

Jennifer Sumner teaches in the Adult Education and Community Development Program at OISE/University of Toronto. Her research interests include sustainable food systems, co-operatives, globalization and critical pedagogy. She is the co-editor of Critical Perspectives in Food Studies (Oxford University Press 2012) and editor of the upcoming Learning, Food and Sustainability: Sites for Resistance and Change (Palgrave Macmillan). Email: jennifer.sumner@utoronto.ca .

Cassie Wever was recently awarded a Masters in Environmental Studies from York University and concurrently obtained a certificate in Environmental and Sustainability Education. Her research interests include the intersections of food, transformative learning experiences, and ecological thinking. Cassie teaches courses in foraging and organic gardening, is a graduate assistant at Black Creek Community Farm, and a research assistant with the Nourishing Communities research group. Email: cassiejwever@gmail.com . 